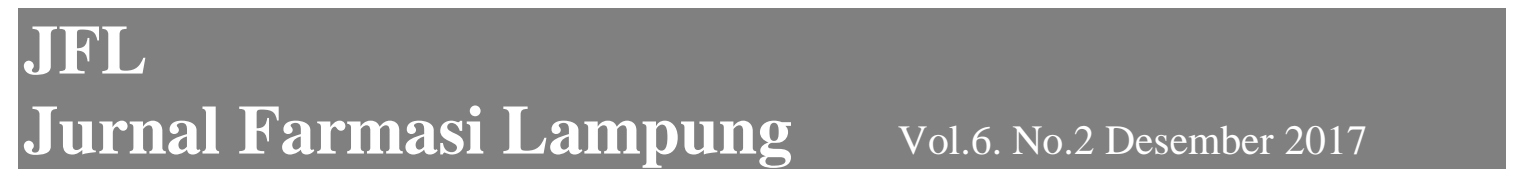

\title{
BIOAKTIVITAS ANTIOKSIDAN SENYAWA EKSOPOLISAKARIDA DARI MIKROALGA Dunaliella sp.
}

Antioxidant Bioactivity Exopolysaccharide Compound From Microalgae Dunaliella Sp.

\author{
Diah Astika Winahyu
}

AKAFARMA Putra Indonesia Lampung

E-mail : astika.diah@gmail.com

\begin{abstract}
A study of antioxidant compounds in microalgae, Dunaliella sp. In Conway / Walne media. Microscope observation with magnification 400 times obtained diameter Dunaliella sp. Sebebsar $6.42 \mu \mathrm{m}$. Preliminary results of antioxidant activity using DPPH reagent showed Dunaliella sp. Excreting antioxidant compounds. The extract obtained by extracting antioxidant compounds exopolysaccharide compounds from the filtrate with the addition of $70 \%$ ethanol and then centrifuged and freeze-dried by the method of FTIR spectrum data dry. Unidentified exopolysaccharide compounds containing uptake helping $\mathrm{O}-\mathrm{H}$ in the area of $3544.82 \mathrm{~cm}-1, \mathrm{C}-\mathrm{H}$ in area of $2828.59 \mathrm{~cm}-1$, helping the $\mathrm{C}$ $=O$ at $1624.24 \mathrm{~cm}-1$ region, $\mathrm{CH} 2$ bending at $1419.44 \mathrm{~cm}-1$ region, and helping $\mathrm{C}-\mathrm{O}$ at $1151.88 \mathrm{~cm}-1$ region. Furthermore, quantitative test results of antioxidant compounds that have a value of $4.279 \%$. So it is concluded that the exopolisakarida compound from Dunaliella sp. Is a potential source of antioxidant compounds.
\end{abstract}

Keywords : Antioxidant, exopolisaccharide, Dunaliella sp.

\begin{abstract}
Abstrak
Mikroalga merupakan mikroorganisme akuatik fotosintesis yang memiliki ukuran mikroskopik. Dunaliella sp. merupakan salah satu contoh mikroalga. Eksopolisakarida merupakan polimer alam yang dapat dihasilkan oleh jenis mikroalga. Sifat material dari eksopolisakarida memiliki aplikasi luas di berbagai bidang kesehatan. Dalam penelitian ini difokuskan pada bioaaktivitas antioksidan senyawa eksopolisakarida dari mikroalga Dunaliella sp. Dunaliella sp. dikultivasi dalam media Conway/Walne. Pengamatan mikroskop diamati dengan menggunakan pembesaran 400 kali diperoleh diameter Dunaliella sp. sebesar 6,42 $\mu \mathrm{m}$. Ekstrak yang diperoleh dengan cara mengekstraksi senyawa antioksidan senyawa exopolysaccharide dari filtrat dengan penambahan etanol $70 \%$ dan kemudian disentrifugasi dan dikeringkan menggunakan metode freeze dry serta data diidentifikasi dengan menggunakan spektrofotometer FTIR. Hasil identifikasisenyawa eksopolisakarida teridentifikasi mengandung serapan uluran $\mathrm{O}-\mathrm{H}$ pada daerah $3544,82 \mathrm{~cm}^{-1}$, C - H pada daerah $2828,59 \mathrm{~cm}^{-1}$, uluran $\mathrm{C}=\mathrm{O}$ pada daerah $1624,24 \mathrm{~cm}^{-1}$, tekukan $\mathrm{CH}_{2}$ pada daerah $1419,44 \mathrm{~cm}^{-1}$, dan uluran $\mathrm{C}-\mathrm{O}$ pada daerah $1151,88 \mathrm{~cm}^{-1}$. Dari data hasil uji kuantitatif senyawa antioksidan memiliki nilai 4,279\%. Jadi disimpulkan bahwa senyawa eksopolisakarida dari Dunaliella sp. merupakan sumber potensial senyawa antioksidan.
\end{abstract}

Keywords : Antioksidan, eksopolisakarida, Dunaliella sp 


\section{PENDAHULUAN}

Indonesia termasuk negara kepulauan dan sekitar $70 \%$ diantaranya merupakan lautan. Lautan diketahui memiliki keanekaragaman hayati yang luar biasa, yang terdiri dari kumpulan organisme termasuk tumbuhan, hewan, mikroorganisme, dan ekosistem di mana organisme tersebut hidup [12]. Salah satu jenisnya adalah mikroalga [8].

Mikroalga merupakan mikroorganisme akuatik berukuran mikroskopik, yang dapat ditemukan di dalam air tawar dan air laut, terdapat pada lokasi yang lembab, serta melakukan proses fotosintesis untuk membuat makanannya sendiri karena termasuk ke dalam jenis makhluk hidup fotoautotrof [1]. Mikroalga memiliki potensi cukup beragam meliputi bidangbidang pertanian, obat-obatan, industri pangan, dan sebagai sumber bioenergi terbaharukan. Berdasarkan nutrisinya, mikroalga merupakan sumber mikronutrisi, vitamin dan trace elemen bagi komunitas perairan [2].

Mikroalga, mampu untuk melakukan fotosintes, mereka menghasilkan oksigen dimana pada waktu yang sama mereka mengambil karbondioksida dilingkungannya sehingga mengurangi efek rumah kaca dan meminimalisasi terjadinya global warming sesuai dengan reaksi berikut:

$\mathrm{CO}_{2}+\mathrm{H}_{2} \mathrm{O}+$ cahaya matahari $\rightarrow$ $\mathrm{CH}_{2} \mathrm{O}+\mathrm{O}_{2}$

Dunaliella sp. termasuk dalam mikroalga halotolerance terhadap salinitas, yaitu memiliki kemampuan hidup dalam kondisi salinitas tinggi [7]. Dunaliella sp. kaya akan kandungan $\beta$ karoten, protein, eksopolisakarida, karotenoid, gliserol, lipid, dan vitamin yang dapat dikembangkan lebih lanjut [13]. Diantara komponen tersebut, eksopolisakarida dari mikroalga telah memperlihatkan aktivitas biologis yang potensial untuk dikaji lebih mendalam.
Eksopolisakarida merupakan polimer alam yang aplikasinya sangat nyata untuk komersial. Biopolimer ini dapat dihasilkan oleh jenis mikroalga tertentu seperti Porphyridium cruentum yang mempunyai prospek untuk diaplikasikan pada spektrum yang luas [3]. Keunggulan eksopolisakarida dihasilkan mikroalga, dibandingkan dengan polimer sintetik yaitu bersifat aman, ekonomis untuk memproduksinya dan bersifat sinambung. Hal ini dikarenakan metode mengkultur mikroalga lebih mudah, cepat serta dapat dilakukan berkesinambungan tanpa batasan lokasi dan iklim setempat, maka senyawa ini berpotensi untuk dikembangkan [4].

Eksopolisakarida dapat berupa homopolimer atau heteropolimer dalam komposisi dan beragam berat molekul yang tinggi. Sifat material dari eksopolisakarida memiliki aplikasi luas di berbagai bidang, prospek aplikasi penggunaan sebagai antikoagulan , antitrombotik , immunomodulation , antikanker dan bioflokulan [6, 9].

Dalam penelitian ini difokuskan pada bioaaktivitas antioksidan senyawa eksopolisakarida dari mikroalga Dunaliella sp. Hal ini dikarenakan senyawa eksopolisakarida dari mikroalga telah memperlihatkan aktivitas biologis yang potensial dan belum banyak dimanfaatkan dan dikelola secara optimal. Sehingga diharapkan akan mendapat senyawa eksopolisakarida yang memiliki manfaat yang lebih baik. Ini tentunya merupakan aset besar yang berpeluang untuk dimanfaatkan dalam pengembangan bioteknologi. 


\section{METODE PENELITIAN}

\section{Alat dan Bahan}

Penelitian dilaksanakan pada bulan Januari 2017. Penelitian ini dilaksanakan di UPT Laboratorium Terpadu dan Sentra Inovasi Teknologi Universitas Lampung.

Dalam penelitian ini alat-alat yang digunakan yaitu seperangkat alat gelas, selang, aerator, cawan petri, pembakar spirtus, mikropipet, autoclave HV 25L HMC, sentrifuse Hitachi/CF16RXII, kaca preparat, neraca analitik, mikroskop (Axioo 10 Carl-Zeiss), Freeze Dryer, spektrofotometer UV-Vis (VarianCary 50 Probe), spektrometer FTIR (Varian - Scimitar 2000),

Bahan - bahan yang digunakan dalam penelitian ini adalah aquadest, alkohol $70 \%$, air laut, natrium hidroksida, fenol, asam klorida, asam sulfat, etanol, komposisi media Conway/Walne.

\section{Prosedur Penelitian}

\section{Kultivasi}

Mikroalga dikultivasi pada media Conway/Walne pada skala laboratorium yakni $500 \mathrm{~mL}$ dan $1000 \mathrm{~mL}$, dengan kondisi kultivasi pada $\mathrm{pH} 7,5-8,5$, suhu $25^{\circ} \mathrm{C}$, serta dilakukan pengamatan secara mikroskopik dengan perbesaran 400 kali.

\section{Pemanenan dan Ekstraksi EPS}

Hasil kultivasi dilakukan pemisahan menggunakan metode sentrifugasi dengan kecepatan 8000 rpm selama 15 menit. Kemudian dilakukan pemisahan antara biomassa dan filtrate. Filtrat kemudian ditambah dengan 30\% etanol, kemudian dilakukan sentrifugasi dengan kecepatan $10000 \mathrm{~g}$ selama 20 menit pada suhu $4{ }^{\circ} \mathrm{C}$. sehingga didapat padatan eksopolisakarida $30 \%$, kemudian padatan dipisah. Pada filtrate, dilakukan penambahan kembali menggunakan etanol menjadi $70 \%$. kemudian dilakukan sentrifugasi dengan kecepatan $10000 \mathrm{~g}$ selama 20 menit pada suhu $4{ }^{\circ} \mathrm{C}$. Sehingga didapat padatan eksopolisakarida $70 \%$. Kemudian dilakukan pengeringan menggunakan freeze dryer.

\section{Identifikasi Spektrofotometer FTIR}

Sampel senyawa peptida yang telah dimurnikan kemudian di pres pada pelet $\mathrm{KBr}$ dengan perbandingan sampel dan $\mathrm{KBr} 1$ : 100. Background yang digunakan adalah pelet $\mathrm{KBr}$ murni. Spektrum direkam pada mode transmitan pada bilangan gelombang $4000-400 \mathrm{~cm}^{-1}$.

\section{Uji Antioksidan}

Uji aktivitas antioksidan juga dilakukan secara kuantitatif menggunakan microplate reader (Anggraini, 2012). Ekstrak kasar ( $\pm 2 \mathrm{mg}$ ) dilarutkan dalam metanol sehingga diperoleh kadar 2000 ppm. Sampel dimasukkan ke dalam plate 96-well sebanyak $100 \mu \mathrm{l}$ dan ditambah dengan $100 \mu$ larutan DPPH $0,2 \mathrm{mM}$ dalam metanol. Blanko yang digunakan adalah metanol. Sampel dan blanko yang sudah ditambahkan larutan DPPH diinkubasi di ruang gelap pada suhu kamar selama 30 menit lalu diukur pada panjang gelombang $492 \mathrm{~nm}$ menggunakan microplate reader. Reaksi positif akan memberikan perubahan warna DPPH dari ungu menjadi kuning.

Persentasi peredaman radikal DPPH oleh senyawa antioksidan dihitung berdasarkan persamaan :

$$
\% \text { Peredaman }=\frac{A_{\text {Blank }}-A_{\text {Test }}}{A_{\text {Blank }}} \times 100 \%
$$

Dimana $A_{\text {blank }}$ merupakan absorbansi balnko dan $A_{\text {test }}$ merupakan absorbansi ekstrak sampel. 


\section{HASIL DAN PEMBAHASAN}

\section{Pengamatan Mikroskop}

Hasil dari pengamatan mikroskop Dunaliella sp. dengan perbesaran 400 kali, hasil pengamatan dengan mikroskop menunjukkan Dunaliella sp. memiliki diameter 6,42 $\mu \mathrm{m}$ dan bentuk morfologi yang normal dapat dilihat pada gambar berikut :

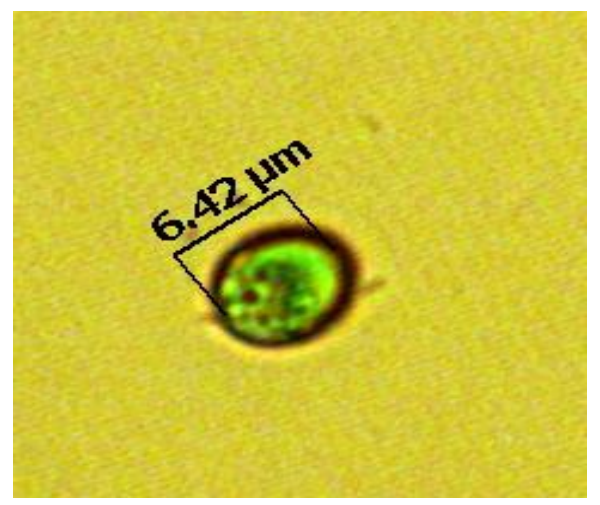

Gambar 1. Pengamatan Mikroskop Dunaliella sp.

\section{Pemanenan dan Ekstraksi EPS}

Pemanenan mikroalga dilakukan dengan metode sentrifugasi. Sedangkan untuk ekstraksi EPS dilakukan penambahan menggunakan etanol menjadi $70 \%$ pada filtrat. kemudian dilakukan sentrifugasi dengan kecepatan $10000 \mathrm{~g}$ selama 20 menit pada suhu $4^{\circ} \mathrm{C}$. Sehingga didapat padatan eksopolisakarida $70 \%$. Kemudian dilakukan pengeringan menggunakan freeze dryer. Hasil EPS yang telah kering dapat dilihat pada gambar 2 berikut ini :

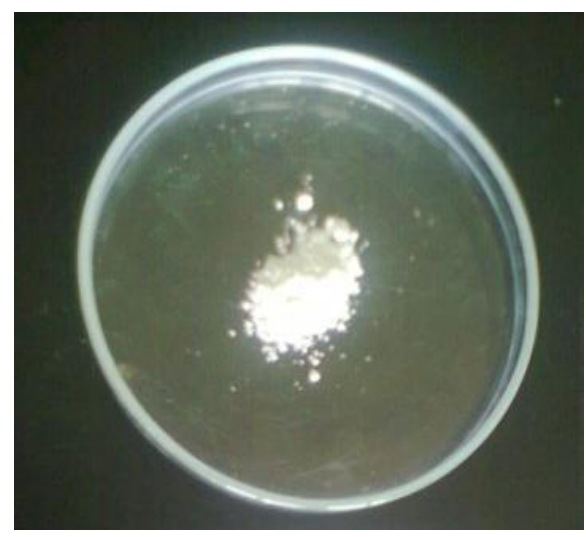

Gambar 2. Eksopolisakarida dari Dunaliella sp.

\section{Identifikasi Menggunakan Spektrofotometer FTIR}

Spektrum inframerah memberikan informasi lebih lengkap tentang gugus fungsional yang terkandung dalam struktur senyawa. Spektrum FTIR senyawa eksopolisakarida ditunjukkan oleh Gambar 3. 


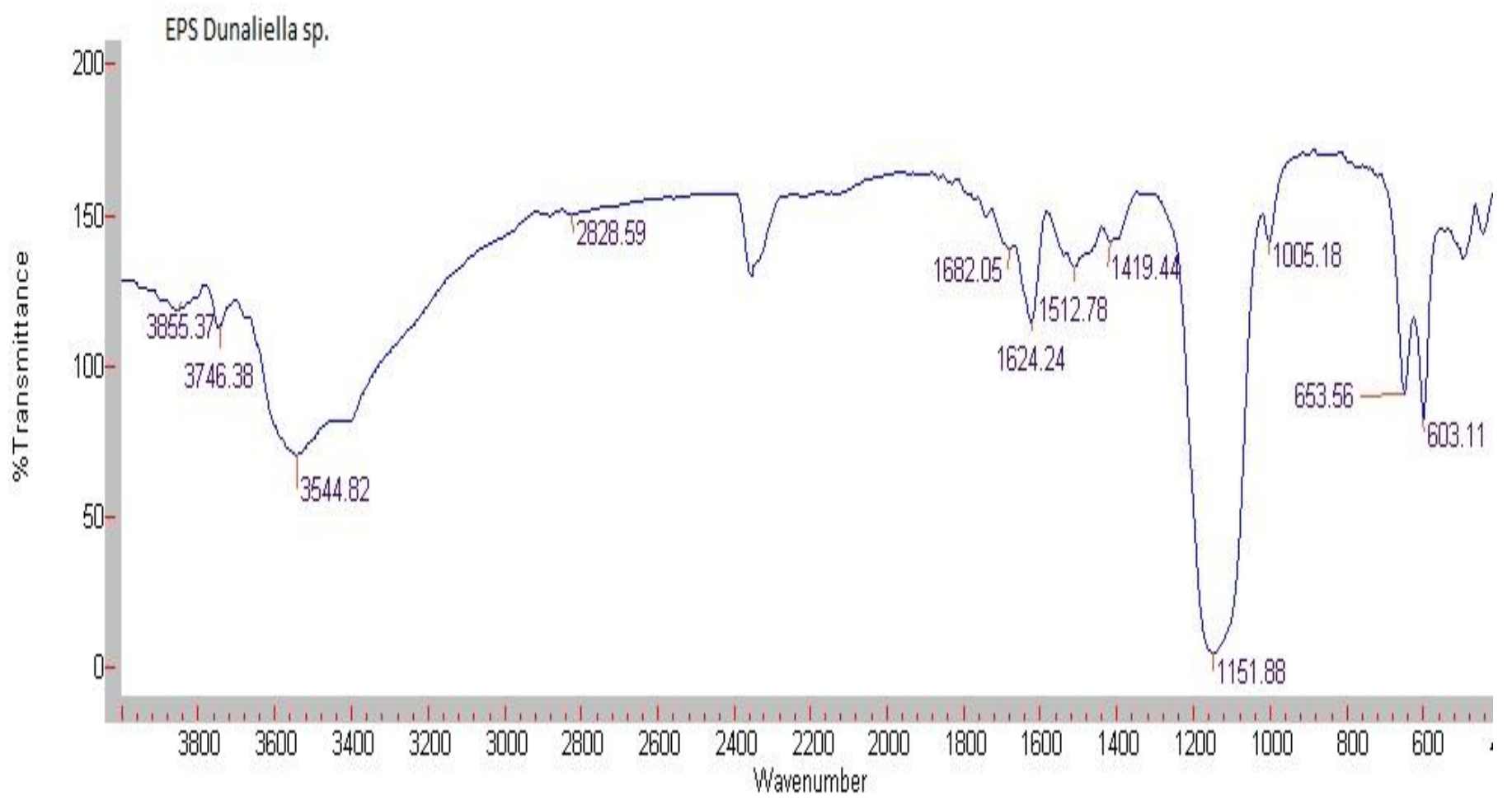

Gambar 3. Spektrum FTIR Senyawa Eksopolisakarida

Dari data Gambar 3, untuk senyawa eksopolisakarida teridentifikasi mengandung serapan uluran $\mathrm{O}-\mathrm{H}$ pada daerah $3544,82 \mathrm{~cm}^{-1}$, C - H pada

\section{Uji Antioksidan}

Dunaliella sp. dikenal kaya akan banyak manfaat yang memiliki beragam aktivitas biologis salah satunya sebagai antioksidan (Richmond and Emeritus, 2013). Senyawa eksopolisakarida hasil isolasi diuji aktivitas antioksidan daerah $2828,59 \mathrm{~cm}^{-1}$, uluran $\mathrm{C}=\mathrm{O}$ pada daerah $1624,24 \mathrm{~cm}^{-1}$, tekukan $\mathrm{CH}_{2}$ pada daerah 1419,44 $\mathrm{cm}^{-1}$, dan uluran C - O pada daerah $1151,8 \mathrm{~cm}^{-1}$.

Tabel 1. Uji aktivitas antioksidan ekstrak awal

\begin{tabular}{l|l|c}
\hline No. & Sampel & Antioksidan (\%) \\
\hline 1. & Blanko & 0,0 \\
\hline 2. & Vit.C & 67,6 \\
\hline 3. & EPS Dunaliella sp. & 4,279 \\
\hline
\end{tabular}


Daya hambat terhadap radikal bebas DPPH diukur menggunakan Plate reader berdasarkan perubahan warna yang terjadi. DPPH (1,1-difenil-2pikrilhidrazil) yang dilarutkan dengan metanol akan berwarna ungu, dan setelah bereaksi dengan sampel yang hidrogen (antioksidan) akan tereduksi menjadi 1,1-difenil-2-pikrilhidrazin [11]. berperan sebagai antioksidan, akan berubah menjadi 1,1-difenil-2pikrilhidrazin yang berwarna kuning. DPPH merupakan suatu radikal bebas yang stabil yang bila bereaksi dengan suatu zat yang dapat menyumbangkan

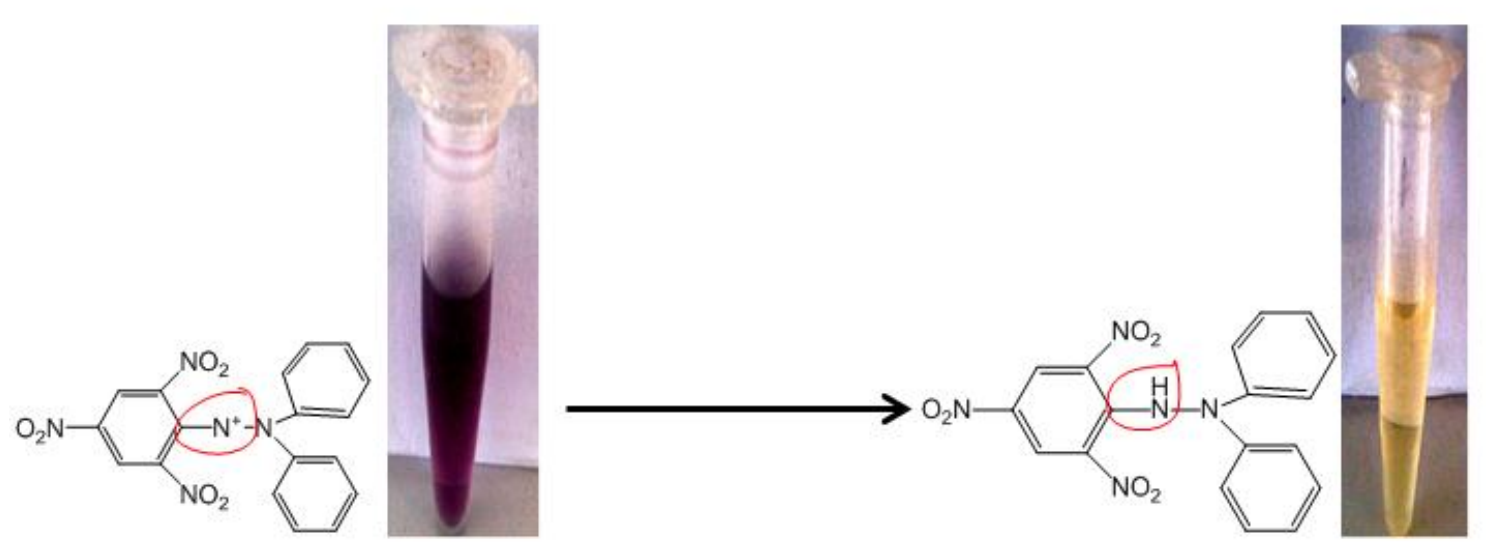

Gambar 4. Hasil perubahan warna DPPH dengan sampel

\section{KESIMPULAN}

Berdasarkan penelitian yang telah dilakukan, maka dapat disimpulkan bahwa :

1. Hasil pengamatan mikroskop dengan perbesaran 400 kali untuk Dunaliella sp. memiliki diameter $6,42 \mu \mathrm{m}$.

2. Senyawa eksopolisakarida dari Dunaliella sp. teridentifikasi mengandung serapan uluran $\mathrm{O}-\mathrm{H}$ pada daerah $3544,82 \mathrm{~cm}^{-1}, \mathrm{C}-\mathrm{H}$ pada daerah $2828,59 \mathrm{~cm}^{-1}$, uluran $\mathrm{C}$ $=\mathrm{O}$ pada daerah $1624,24 \mathrm{~cm}^{-1}$, tekukan $\mathrm{CH}_{2}$ pada daerah 1419,44 $\mathrm{cm}^{-1}$, dan uluran $\mathrm{C}-\mathrm{O}$ pada daerah $1151,88 \mathrm{~cm}^{-1}$.

3. Senyawa eksopolisakarida dari Dunaliella sp. memiliki aktivitas antioksidan.

\section{SARAN}

Dari hasil penelitian ini, penulis menyarankan agar dilakukan pemurnian senyawa eksopolisakarida dan dilakukan identifikasi penetuan struktur senyawa yang didapat.

\section{UCAPAN TERIMA KASIH}

Pada kesempatan ini penulis berterimakasih kepada Akademi Farmasi dan Makanan Putra Indonesia Lampung yang telah memberi kesempatan kepada penulis untuk menyelesaikan penulisan karya ilmiah ini. 


\section{JFL \\ Jurnal Farmasi Lampung

\section{DAFTAR PUSTAKA}

[1] Sukara, E. 2006. Biotrends. Puslit Bioteknologi LIPI. Majalah Populer Bioteknologi. Vol. 1 No.2.

[2] Richmond, A. and Qiang Hu. 2013. Handbook of Microalgal Culture Applied Phycology and Biotechnology. Wiley-Blackwell.

[3] Anderson, R.A. 2005. Algae Culturing Technique. Elsevier Academic Press. London.

[4] Barsanti, Laura and Paolo Gualtieri. 2006. Algae Anatomy, Biochemistry and Biotechnology. Taylor \& Francis Group, the academic division of T\&F Informa plc.

[5] Pisal S Dipak dan S S lele. 2005. Carotenoid from Microalga, Dunaliella salina. Biotechnology. 476-483.

[6] Wu Q., Cheng Zheng, Zheng-Xiang Ning and Bao Yang. 2007. Modification of Low Molecular Weight Polysaccharides from Tremella Fuciformis and Their Antioxidant Activity in Vitro. J. Mol. Sci. 2007, 8, 670-679.

[7] García-González, M, Moreno, J, Manzano, J.C, Florêncio, F.J, Guerrero, M.G. 2005. Production of Dunaliella salina biomass rich in 9cis- $\beta$-carotene and lutein in a closed tubular photobioreactor. $J$. Biotechnol. 115, 81-90.

[8] Harutoshi, T. 2013.

Exopolysaccharides of Lactic Acid Bacteria for Food and Colon Health Applications. licensee InTech.
[9] Nwodo, U. U., Ezekiel Green and Anthony I. Okoh. 2012. Bacterial Exopolysaccharides: Functionality and Prospects. Int. J. Mol. Sci. 13, 14002-14015.

[10] Sajna, K. V., Rajeev K. Sukumaran, Lalitha Devi Gottumukkala, Himani Jayamurthy, Kiran S. Dhar, Ashok Pandey. 2013. Studies on structural and physical characteristics of a novel exopolysaccharide from Pseudozyma sp. NII 08165. International Journal of Biological Macromolecules. 84- 89

[11] Molyneux, R.J. 2009. Bioactive Natural Product, Detection, Isolation and Structural Determination 2nd Edition. CRC Press. Taylor and Francis. United States. 